\title{
Optimized extraction of a lectin from Crataeva tapia bark using AOT in isooctane reversed micelles
}

\author{
Cynthia O. Nascimento ${ }^{\mathrm{a} b}$, Romero M.P.B. Costa ${ }^{\mathrm{a}, \mathrm{b}}$, Regina M.S. Araújo ${ }^{\mathrm{a}}$, Maria E.C. Chaves $^{\mathrm{a}, \mathrm{b}}$, \\ Luana C.B.B. Coelho ${ }^{a}$, Patrícia M.G. Paiva ${ }^{a}$, José A. Teixeira ${ }^{c}$, \\ Maria T.S. Correia ${ }^{a}$, Maria G. Carneiro-da-Cunha ${ }^{\mathrm{a}, \mathrm{b}, *}$ \\ ${ }^{a}$ Departamento de Bioquímica, Centro de Ciências Biológicas, Universidade Federal de Pernambuco (UFPE), Av. Prof. Moraes Rego s/n, 50.670-420 Recife, PE, Brazil \\ ${ }^{\mathrm{b}}$ Laboratório de Imunopatologia Keizo Asami-LIKA/UFPE, Recife, PE, Brazil \\ ${ }^{\mathrm{c}}$ IBB-Institute for Biotechnology and Bioengineering, Centre for Biological Engineering, Universidade do Minho, Campus de Gualtar 4710-057, Braga, Portugal
}

\section{A R T I C L E I N F O}

\section{Article history:}

Received 14 November 2007

Received in revised form 14 February 2008

Accepted 29 February 2008

\section{Keywords:}

Liquid-liquid extraction

Reversed micelles

Sodium di(2-ethylhexyl)sulfosuccinate

(AOT)

Purification

Lectin

Crataeva tapia

\begin{abstract}
A B S T R A C T
Crataeva tapia bark lectin was extracted from a crude extract into a reversed micelle phase of the anionic surfactant AOT in isooctane and back-extracted, to a final aqueous phase by addition of butanol. The effects of $\mathrm{pH}$, ionic strength and surfactant concentration on the protein transfer process from the aqueous to the organic phase were characterized, being the best results obtained after 5 min of contact, under agitation, between the two phases, at pH 5.5 (10 mM citrate-phosphate buffer), $30 \mathrm{mM} \mathrm{NaCl}$, and $5 \mathrm{mM}$ AOT. Recovery to a new aqueous phase was performed with 5 min of contact, under agitation, $10 \mathrm{mM}$ citrate-phosphate buffer at $\mathrm{pH} 5.5,500 \mathrm{mM} \mathrm{KCl}$ and $5 \%$ of butanol. The overall yield obtained for the process was $80 \%$ for lectin activity and $56 \%$ for protein recovery. The efficiency of the process was confirmed by SDS-PAGE analysis.
\end{abstract}

(c) 2008 Elsevier Ltd. All rights reserved.

\section{Introduction}

Lectins occur ubiquitously in nature and are important in medicine and technology. Most lectins are basically non-enzymic in action and non-immune in origin. They may bind to a carbohydrate moiety that is in solution or to one that is a part of protein/particulate body. They can agglutinate cells and/or precipitates glycoconjugates [1]. Plant seeds and bark provide a major source from which lectins are isolated. Some plant lectins appear to have pharmacological activity [2]. For example, in the northeast of Brazil Crataeva tapia bark infusions have been used in popular medicine as hypoglycemic agent.

Protein extraction from aqueous solution by reverse micelles is a process that utilizes basic techniques of chemical engineering such as classical liquid-liquid extraction, and thus has the potential for industrial application [3]. This process can be used to separate biological products such as, proteins, which have been solubilized in organic solvents using surfactants, without affecting their functional properties [4]. The process can be performed by a

\footnotetext{
* Corresponding author at: Departamento de Bioquímica, Centro de Ciências Biológicas, Universidade Federal de Pernambuco (UFPE), Av. Prof. Moraes Rego s/n, 50.670-420 Recife, PE, Brazil. Fax: +55 8121268576.

E-mail address: mgcc@ufpe.br (M.G. Carneiro-da-Cunha).
}

forward extraction of the target protein or contaminants, from an aqueous solution to a reversed micellar organic phase, followed by back-extraction, during which the biomolecules are released from micelles and transferred to a new aqueous phase [5], recent examples being the extraction of a lysozyme and ovalbumin [6], chitanases [7], $\alpha$-amylase [8] and nattokinase [9].

In this work, the extraction and purification of a new thermostable plant lectin from C. tapia bark was studied using a reversed micelle system of the anionic surfactant sodium di(2ethylhexyl)sulfosuccinate (AOT) in isooctane. Process optimization was performed by addition of butanol and manipulation of $\mathrm{pH}$, ionic strength and surfactant concentration.

\section{Materials and methods}

\subsection{Chemicals}

Sodium di(2-ethylhexyl)sulfosuccinate was obtained from Sigma (USA): isooctane, butanol and glutaraldehyde were obtained from Merck (Germany); bicinchoninic acid (BCA) was obtained from Pierce. All other chemicals were of analytical grade.

\subsection{Preparation of extract}

C. tapia bark was collected in the region of Recife city (Pernambuco, Brazil) and the extract was obtained by pulverizing dried bark [10\% (w/v) in $150 \mathrm{mM} \mathrm{NaCl}]$ followed by agitation overnight at $4{ }^{\circ} \mathrm{C}$. Afterwards, the extract was filtered through 
a gauze and the filtrate centrifuged at $4000 \times g$ for $15 \mathrm{~min}$. The supernatant was termed crude extract (CE).

\subsection{Extraction and back-extraction of protein with reversed micelles}

The reversed micellar system was constituted using the anionic surfactant, sodium di(2-ethylhexyl)sulfosuccinate in isooctane. Extraction and back-extraction procedures were performed as follows: (1) to buffered lectin preparations ( $3 \mathrm{ml})$ at different $\mathrm{pH}$ (10 mM citrate-phosphate, $\mathrm{pH}$ 3.0-6.0, $10 \mathrm{mM}$ sodium-phosphate, $\mathrm{pH}$ 7.0, $10 \mathrm{mM}$ Tris- $\mathrm{HCl}, \mathrm{pH}$ 8.0, $10 \mathrm{mM}$ carbonate-bicarbonate, $\mathrm{pH} 9.0-10.0$ and $10 \mathrm{mM}$ glycine- $\mathrm{NaOH}, \mathrm{pH} 11.0-12.0$ ) containing $30 \mathrm{mM} \mathrm{NaCl}$, an equal volume $(3 \mathrm{ml}$ ) of micellar phase (AOT in isooctane at a concentration range of 0.125 $100 \mathrm{mM}$ ) was added and both phases were stirred for $5 \mathrm{~min}$ for protein extraction. The mixture was then centrifuged for $5 \mathrm{~min}$ at $3000 \times \mathrm{g}$, for phase separation. (2) After extraction, the separated micellar phase $(2 \mathrm{ml})$, containing solubilized protein, was added to an equivalent volume of buffered aqueous solution at different $\mathrm{pH}$ (10 mM citrate-phosphate, $\mathrm{pH} 5.0-6.0$ and $10 \mathrm{mM}$ sodium-phosphate, $\mathrm{pH} 7.0$ ) containing $50-1000 \mathrm{mM} \mathrm{KCl}$ and $5 \%(\mathrm{v} / \mathrm{v})$ of butanol was added to the system. The mixture was stirred for $5 \mathrm{~min}$, centrifuged for $5 \mathrm{~min}$ at $3000 \times \mathrm{g}$ for phase separation and the lectin recovered to the new aqueous phase. Agitation speed $(700 \mathrm{rpm})$, temperature $\left(25^{\circ} \mathrm{C}\right)$ and initial protein concentration $(0.374 \mathrm{mg} / \mathrm{ml})$ were kept constant in all experiments.

\subsection{Protein assays}

The protein content in the aqueous and organic phases was spectrophotometrically determined using the bicinchoninic acid according to Smith et al. [10], with bovine serum albumin as standard, at a range of $0-600 \mu \mathrm{g} / \mathrm{ml}$.

\subsection{Determination of the hemagglutinating activity}

The determination of the hemagglutinating activity (HA) in the aqueous phase was performed in microtiter plates according to Correia and Coelho [11]. Lectin preparations $(50 \mu \mathrm{l})$ were two-fold serially diluted with $0.15 \mathrm{M} \mathrm{NaCl}$ before addition of $50 \mu \mathrm{l}$ suspension of rabbit erythrocytes treated with glutaraldehyde $2.5 \%(\mathrm{v} / \mathrm{v})$. The HA was expressed as the log of the highest dilution exhibiting hemagglutination. The determination of the activity in the back-extraction aqueous phase was carried out after dialysis due to the interference of salt concentration used. The protein hemagglutinating activity was not measured in organic phase, due to interference of the organic solvent (micellar phase). The specific HA (SHA) was given by the ratio between $\mathrm{HA}$ and protein content $(\mathrm{mg} / \mathrm{ml})$. The purification factor (PF) as follows:

$\mathrm{PF}=\underline{\text { SHA in new aqueous phase after back-extraction }}$ SHA in initial aqueous phase

\subsection{Polyacrylamide gel electrophoresis (PAGE)}

Electrophoresis in the presence of sodium dodecyl sulfate (SDS-PAGE) was performed on $10 \%(\mathrm{w} / \mathrm{v})$ gel according to Laemmli [12]. Polypeptide bands of lectin (150 $\mu \mathrm{g}$ of protein) and standards [bovine serum albumin, $66 \mathrm{kDa}$; ovalbumin, $45 \mathrm{kDa}$; carbonic anhydrase, $29 \mathrm{kDa}$; lysozyme, $14.3 \mathrm{kDa}$ from Sigma (USA)] were stained with Coomassie Brilliant Blue. PAGE for native basic $[7.5 \%(\mathrm{w} / \mathrm{v})$ gel] and acidic [12\% ( $\mathrm{w} / \mathrm{v})$ gel] proteins were performed according to Reisfeld et al. [13] and Davis [14], respectively.

\subsection{Gel filtration chromatography}

Lectin extracted by reversed micelles was chromatographed on gel filtration on a Hiprep 16/60 Sephacryl S-300 column $(16 \mathrm{~mm} \times 60 \mathrm{~cm}) /$ Akta FPLC system (Amersham Pharmacia Biotech, Sweden) pre-equilibrated at $24{ }^{\circ} \mathrm{C}$ with $0.5 \mathrm{M}$ $\mathrm{NaCl}$. Samples $(2.0 \mathrm{ml} ; 1 \mathrm{mg}$ of protein) were injected and eluted with the same solution at a flow rate of $3.0 \mathrm{ml} / \mathrm{min}$. The standards (Sigma, USA) similarly chromatographed were bovine serum albumin ( $66 \mathrm{kDa}$ ), fetuin (64 kDa), ovalbumin (45 kDa) and trypsin inhibitor type III-O chicken (28 kDa).

\section{Results and discussion}

\subsection{Effect of $\mathrm{pH}$ on the extraction}

The major determining factors on protein solubilization in reversed micellar systems are electrostatic interactions among biomolecules and charged surfactant heads as well as the aggregation properties of surfactant. $\mathrm{pH}$ influence on lectin extraction was evaluated for a $30 \mathrm{mM} \mathrm{NaCl}$ aqueous phase and $5 \mathrm{mM}$ AOT/isooctane. The $\mathrm{pH}$ of the aqueous phase (CE) was varied between 3.0 and 12.0, using different buffer systems according to

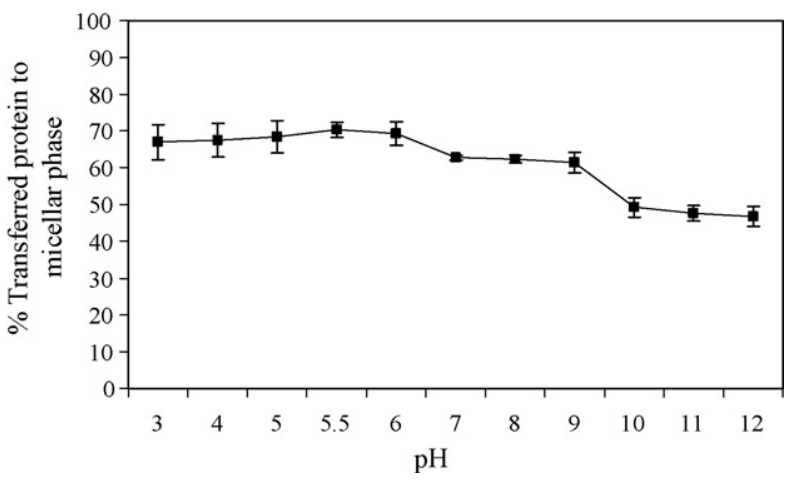

Fig. 1. Effect of pH on lectin extraction with $30 \mathrm{mM} \mathrm{NaCl}, 5 \mathrm{mM}$ AOT in isooctane reversed micelles. Buffers: $\mathrm{pH}$ 3.0-6.0 (10 mM citrate-phosphate); $\mathrm{pH} 7.0$ (10 mM sodium-phosphate); pH 8.0 (10 mM Tris- $\mathrm{HCl}$ ); pH 9.0-10.0 (10 mM carbonatesodium bicarbonate); $\mathrm{pH} 11.0-12.0$ (10 mM glycine- $\mathrm{NaOH}$ ). Each data point is an average of three experiments and the error bars show the standard deviation.

their $\mathrm{p} K_{\mathrm{a}}$ value (Fig. 1). The results showed a high transfer of protein to the micellar phase within the $\mathrm{pH}$ range of 3.0-6.0, with a maximum of ca. 70\% at pH 5.5. A similar situation has been reported for Cratylia mollis seed lectin [15], with a maximum extraction at $\mathrm{pH}$ 5.0. This behaviour suggests that $\mathrm{pH} 5.5$ was more selective, probably due to favorable attractive electrostatic interactions between positively charged lectin molecules at $\mathrm{pH} 5.5$ (lectin has a $\mathrm{pI} 9.5$ as previously determined in our laboratory) and negatively charged surfactant heads. For smaller proteins, using anionic surfactants at $\mathrm{pH}$ conditions below the protein $\mathrm{pI}$ their transfer from aqueous to micellar solution is favoured [16]. As the $\mathrm{pH}$ of aqueous phase increased from 5.5 to 12 , the extracted protein decreased ca. of $34 \%$ probably due to the proximity of the isoelectric point of the lectin. This phenomenon was observed for different proteins at distinct isoelectric points [17]. The protein hydrophobic patches exposed may interact with anionic surfactant hydrophobic tails minimizing extraction. Besides the protein charge, the density of surface charge is an important factor on protein solubilization. Therefore, the selected $\mathrm{pH}$ to be used in further experiments was 5.5.

\subsection{Effect of AOT concentration on the extraction}

Protein solubilization is strongly dependent on the concentration of surfactant and on the size of the micelle relative to that of the protein. Before analysing the effect of AOT concentration on lectin purification the critical micellar concentration was determined as being $1 \mathrm{mM}$ AOT, which is in agreement with results presented by Yan-ching and Ache [18]. For a AOT concentration of $0.125 \mathrm{mM}$, no phase separation occurred and for AOT concentrations of 0.25 and $0.50 \mathrm{mM}$ an apparent phase separation (aqueous phase/micellar phase) was observed, but no protein was transferred to the micellar phase while on the other hand, 78.8 and $82.11 \%$ of protein formed a clearly visible precipitate at the interface, respectively. For AOT concentrations higher than the $\mathrm{cmc}$ (1-100 mM AOT), the influence of AOT concentration on lectin extraction under $30 \mathrm{mM}$ of $\mathrm{NaCl}$ and $\mathrm{pH} 5.5$, was evaluated (Fig. 2). The results showed that protein extraction was ca. 60\% at AOT concentration between 1 and $3 \mathrm{mM}$, remaining constant at $70 \%$ for AOT concentrations between 5 and $50 \mathrm{mM}$ with a $5 \%$ decrease for $100 \mathrm{mM}$ AOT. It is well known that the increase in the amount of surfactant in organic phase leads to an increase of protein solubilization due to the increase of the amount of surfactant aggregation and/or the increase of size of reverse micelles [19]. Nevertheless, no significant differences were found on extraction over AOT concentration range of 5-50 mM. These results could be explained by the size of lectin associated to a strong electrostatic 


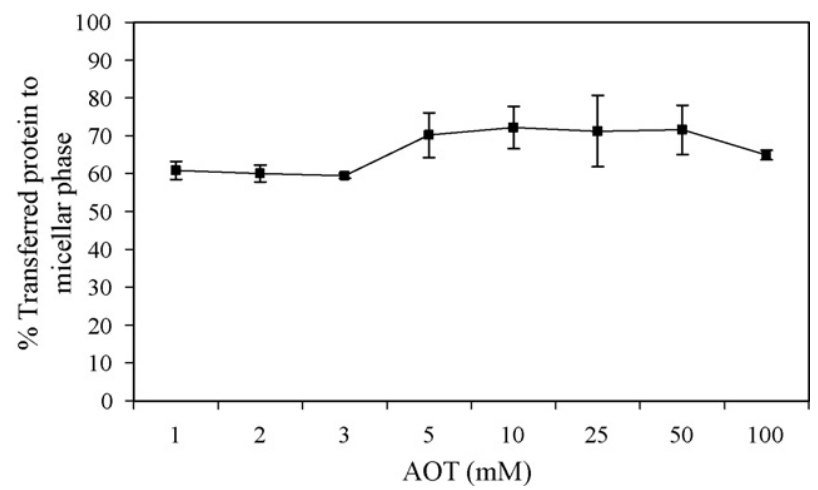

Fig. 2. Effect of AOT concentration on lectin extraction under $30 \mathrm{mM}$ of $\mathrm{NaCl}$ and $\mathrm{pH}$ 5.5 conditions during forward transfer to micellar phase. Each data point is an average of three experiments and the error bars show the standard deviation.

interaction between protein and surfactant due to the basic nature of the lectin. A similar situation has been reported for the extraction of a lipase from Penicillium citrinum across an AOT concentration range of $100-350 \mathrm{mM}$ [20]. Taking in account these results, the $5 \mathrm{mM}$ AOT concentration was chosen for the following experiments since it might be expected that a high surfactant concentration makes difficult the backward transfer of proteins into a second aqueous phase [4].

\subsection{Effect of $\mathrm{pH}$ and ionic strength on the back-extraction}

The back-extraction step was more difficult to accomplish, probably due either to the strong electrostatic interactions between positive lectin charge and negative charge of AOT or possibly the high affinity between the protein and the surfactant. A small amount of alcohol added to an organic solution can improve the back-extraction behaviour of proteins depending on the concentration and alcohol species used [21]. For example, the presence of butanol in the system may change the water properties inside reversed micelles [22] and may affect protein-micelle interactions in a fundamental manner [23]. For this reason 5\% butanol was used during back-extraction. Fig. 2 shows that the amount of protein back-extracted to the new aqueous phase increased with the increase of $\mathrm{pH}$ value and $\mathrm{KCl}$ concentration with a maximum recovery (85\%) at $\mathrm{pH} 7.0$ containing $500 \mathrm{mM} \mathrm{KCl}$. A further increase in the $\mathrm{KCl}$ concentration did not result in a higher content of back-extracted protein or a higher purification factor. This electrostatic screening effect may also be responsible for the decrease of the surfactant head group repulsions, leading to smaller reversed micelles [4], which in turn, could be a factor responsible for the higher back-extraction of proteins to the aqueous solution. However, we found that $\mathrm{KCl}$ concentrations higher than $500 \mathrm{mM}$ did not increase the recovery of the protein. This may well be due to the fact that the electrostatic effect reached a maximum at $500 \mathrm{mM} \mathrm{KCl}$. While the higher back-extraction (85\%) was found at $\mathrm{pH} 7.0$, a better purification factor (1.7) was obtained at pH 5.5 (Fig. 3) with $500 \mathrm{mM} \mathrm{KCl}$. These results suggest that the increased percentage of protein transferred into a new aqueous phase when $\mathrm{pH}$ was increased from 5.5 to 7.0 was not due to higher lectin content but to other contaminant proteins. Similar purification factors of protein, 1.8 and 1.5, using micellar systems have been reported for an extracellular alkaline protease from fermentation broth [22] and for a xylanase from fermentation broth [24], respectively. The presence of butanol in the system permitted the back-extraction of lectin from a reversed micellar phase to an aqueous phase, as a consequence of a structural factor change of the micelles, corroborated by Liu et al. [9], and Lee et al

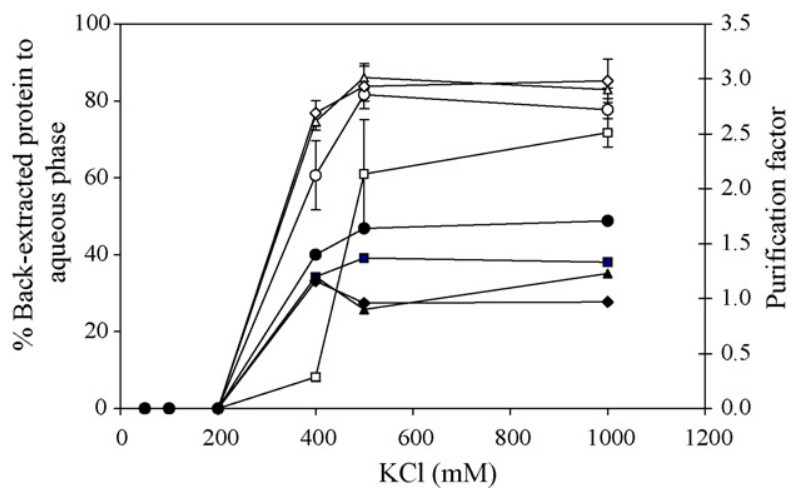

Fig. 3. Effect of $\mathrm{pH}$ and ionic strength on back-extraction at $\mathrm{pH} 5.5$, with $5 \mathrm{mM}$ AOT in isooctane reversed micelles to a new $10 \mathrm{mM}$ buffered aqueous phase at pH 5.0 $(\square), 5.5(\bigcirc)$ and $6.0(\triangle)$ (with citrate-phosphate) and pH $7.0(\diamond)$ (with sodiumphosphate) with addition of $\mathrm{KCl}$ concentrations of $50-1000 \mathrm{mM}$. Initial concentration of protein in micellar phase $=0.260 \mathrm{mg} / \mathrm{ml}$ and initial $\log \mathrm{HA}=1.5$. Key: open symbols, \% back-extracted protein to aqueous phase; closed symbols, purification factor. Each data point is an average of three experiments and the error bars show the standard deviation. (a)

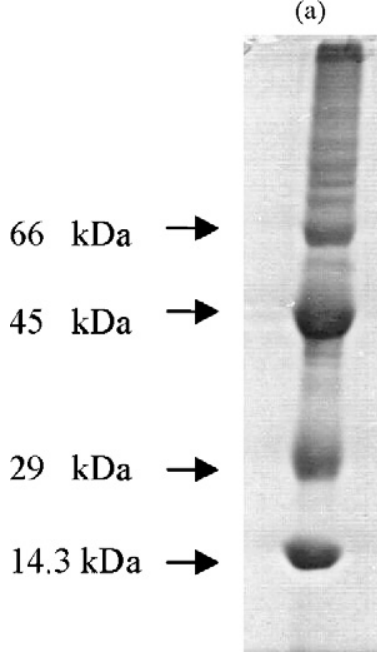

(b)

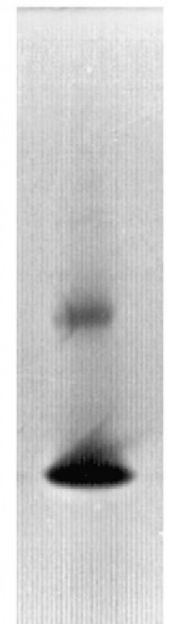

(c)

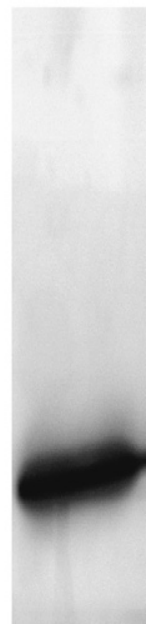

Fig. 4. PAGE of back-extracted sample at $\mathrm{pH} 5.5$, containing $500 \mathrm{mM} \mathrm{KCl}$ with the addition of $5 \%(\mathrm{v} / \mathrm{v})$ butanol at $25{ }^{\circ} \mathrm{C}$. SDS-PAGE: (a) molecular weight markers and (b) lectin purified by reversed micelles; (c) PAGE for native basic protein: lectin purified by reversed micelles.

[21]. The optimal condition for direct extraction of lectin from crude extract led to a recovery of $56 \%$ with retention of, at least, $80 \%$ of the lectin HA.

\subsection{Structural characterization of purified lectin by reversed micellar system}

Electrophoresis was applied to the purified lectin as previously described. SDS-PAGE showed two polypeptide bands of molecular mass 21 and $40 \mathrm{kDa}$ (Fig. 4a and b) while PAGE for native basic protein revealed a single lectin band (Fig. 4c) and no acidic protein band was detected. The evaluation of purified lectin by gel filtration chromatography (Fig. 5a) revealed two protein peaks corresponding to 40 and $29 \mathrm{kDa}$. When the crude extract was applied to the chromatography column (Fig. 5b) one main peak of $40 \mathrm{kDa}$ and additional peaks of 26, 19 and $7.6 \mathrm{kDa}$ were detected. At $29 \mathrm{kDa}$, a very small peak was also observed. The chromatographic profiles obtained indicate the efficiency of the reversed micellar system for lectin purification as none of the contaminants detected on the crude extract were observed in the purified 

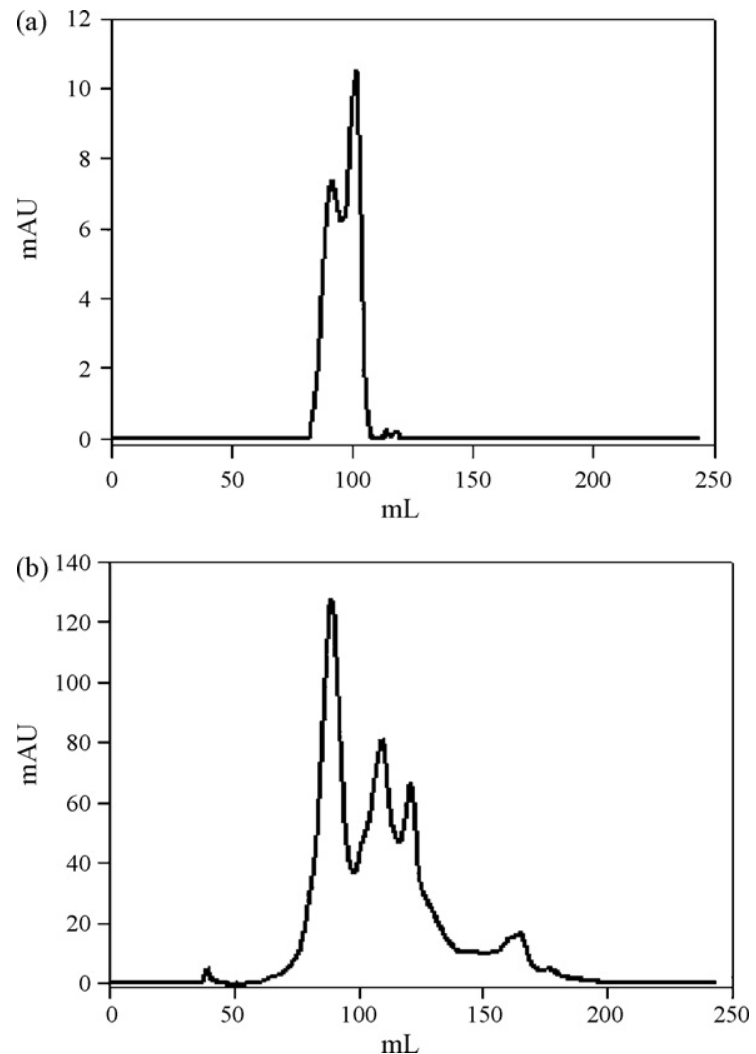

Fig. 5. Gel filtration chromatography on Sephacryl S-300: (a) purified lectin ( $2 \mathrm{ml}$; $0.3 \mathrm{mg})$ applied on column $(16 \mathrm{~mm} \times 60 \mathrm{~cm})$ equilibrated with $500 \mathrm{mM} \mathrm{NaCl}$ and (b) crude extract ( $2 \mathrm{ml} ; 4 \mathrm{mg})$. Fractions $(3 \mathrm{ml}$ ) were collected at $1.0 \mathrm{ml} / \mathrm{min}$.

preparation. The two peaks detected by gel filtration chromatography under non-denaturing conditions for the purified lectin reflect the presence of aggregated and non-aggregated protein as already observed in SDS-PAGE (Fig. 4b). The obtention of a $29 \mathrm{kDa}$ fraction by gel filtration chromatography, as compared to the $21 \mathrm{kDa}$ fraction obtained by SDS, may be due to the incomplete unfolding of the non-aggregated lectin that occurs on the presence of SDS denaturing conditions.

\section{Conclusion}

The utilization of reverse micelles on lectin extraction and purification from a crude extract was successfully applied using an AOT/isooctane/water biphasic system with the addition of butanol on the back-extraction step and adjustment of $\mathrm{pH}$, ionic strength and AOT concentration. Although the maximum recovery (85\%) was found to be at $\mathrm{pH} 7.0$ with $500 \mathrm{mM} \mathrm{KCl}$, the highest purification factor (1.7) was found to be at the same $\mathrm{pH}$ level (5.5) found on the extraction step. Being so, the $\mathrm{pH}$ value of 5.5 was established as a compromise between the maximum activity (80\%) and protein (56\%) recovery. These results were obtained using a $10 \mathrm{mM}$ citrate-phosphate buffer solution, pH 5.5 containing $30 \mathrm{mM} \mathrm{NaCl} ; 5 \mathrm{mM}$ AOT and $5 \mathrm{~min}$ agitation for the extraction step and a $10 \mathrm{mM}$ citrate-phosphate buffer solution, $\mathrm{pH} 5.5$ containing $500 \mathrm{mM} \mathrm{KCl}$ plus $5 \%$ of butanol and 5 min agitation for the back-extraction. This purification procedure allows for the obtention of a high purity lectin allowing for its further in vivo evaluation as a hypoglycemic agent.

\section{Acknowledgements}

The authors are deeply grateful to MBR Silva, JA Virgínio for the technical assistance, ALFA/VALNATURA (AML/B7-311/97/0666/II0440-FA) and CNPq for financial support (Proc. 472529/2006-4/ MCT/CNPq 02/2006-Universal) and to Dr. David Bousfield for his valuable suggestions and language revision.

\section{References}

[1] Sharon N, Lis H. The structural basis for carbohydrate recognition by lectins. In: $\mathrm{Wu}$, editor. The molecular immunology of complex carbohydrates- 2 . Taiwan: Kluwer Academic/Plenum Publishers; 2001. p. 1-16.

[2] Guerrero RO, Rohledo L. Endemic plants of Puerto Rico: brine shrimp lethality and antibacterial activity. P R Health Sci J 1993;12:259-62.

[3] Hasmann FA, Cortez DV, Gurpilhares DB, Santos VC, Roberto IC, Pessoa-Junior A. Continuous counter-current purification of glucose-6-phosphate dehydrogenase using liquid-liquid extraction by reverse micelles. Biochem Eng 2007;34:236-41.

[4] Monteiro TIRC, Porto TS, Carneiro-Leão AMA, Silva MPC, Carneiro-da-Cunha MG. Reversed micellar extraction of an extracellular protease from Nocardiopsis sp. fermentation broth. Biochem Eng J 2005;24:87-90.

[5] Carneiro-da-Cunha MG, Melo EP, Cabral JMS, Aires-Barros MR. Liquid-liquid extraction of a recombinant cutinase from fermentation media with AOT reversed micelles. Bioproc Eng 1996;15:151-7.

[6] Yang L, Xiao-Yan D, Yan S. Protein separation by affinity extraction with reversed micelles of Span 85 modified with cibacron blue F3G-A. Sep Purif Technol 2007;53:289-95.

[7] Chen YL, Su CK, Chiang BH. Optimization of reversed micellar extraction of chitosanases produced by Bacillus cereus. Process Biochem 2006;41:752-8.

[8] Tonova K, Lazarova Z. Influence of enzyme aqueous source on RME-based purification of $\alpha$-amylase. Sep Purif Technol 2005;47:43-51.

[9] Liu JG, Xing JM, Shen R, Yang CL, Liu HZ. Reverse micelles extraction of nattokinase from fermentation broth. Biochem Eng J 2004;21:273-8.

[10] Smith PK, Krohn RJ, Hermanson GT, Mallia AK, Gardner FH, Provenzano MD, et al. Measurement of protein using bicinchoninic acid. Anal Biochem 1985; $150: 76-85$.

[11] Correia MTS, Coelho LCBB. Purification of a glucose/manose specific lectin, isoforma 1, from seeds of Cratylia mollis Mart. (Camaratu Bean). Appl Biochem Biotechnol 1995;55:261-73.

[12] Laemmli UK. Cleavage of structural proteins during the assembly of the head of bacteriophage T4. Nature 1970;227:680-5.

[13] Reisfeld RA, Lewis UJ, Williams DE. Disk electrophoresis of basic proteins and peptides on polyacrylamide gels. Nature 1962;195:281-3.

[14] Davis BJ. Disc electrophoresis II: method and application to human serum proteins. Ann N Y Acad Sci 1964;121:404-27.

[15] Nascimento CO, Coelho LCBB, Correia MTS, Carneiro-da-Cunha MG. Liquidliquid extraction of lectin from Cratylia mollis seeds using reversed micelles. Biotechnol Lett 2002;24:905-7.

[16] Pessoa-Júnior A, Vitolo M. Recovery of inulinase using BDBAC reversed micelles. Process Biochem 1998;33:291-7.

[17] Goklen KE, Hatton TA. Liquid-liquid extraction of low molecular weight proteins by selective solubilization in reversed micelles. Sep Sci Technol 1987;22:831-41.

[18] Yan-ching J, Ache HJ. Study of the micelle formation and the effect of additives on this process in reversed micellar systems by positron annihilation techniques. J Am Chem Soc 1978;100:6320-7.

[19] Nishiki T, Nakamura K, Kato D. Forward and backward extraction rates of amino acid in reversed micellar extraction. Biochem Eng J 2000;4:189-95.

[20] Krieger N, Taipa MA, Aires-Barros MR, Melo EHM, Lima-Filho JL, Cabral JMS. Purification of Penicillium citrinum lipase using AOT reversed micelles. J Chem Technol Biotechnol 1997;69:77-85.

[21] Lee SS, Hwang KS, Lee BK, Hong DP, Kuboi R. Interaction between reverse micelles as a key factor governing back-extraction of proteins and its control systems. Korean J Chem Eng 2005;22:611-6.

[22] Porto TS, Monteiro TIR, Moreira KA, Lima-Filho JL, Silva MPC, Porto ALF, et al Liquid-liquid extraction of an extracellular alkaline protease from fermentation broth using aqueous two-phase and reversed micelles systems. World J Microbiol Biotechnol 2005;21:655-9.

[23] Hong DP, Kuboi R. Evaluation of the alcohol-induced interaction between micelles using percolation processes of reverse micellar systems. Biochem Eng J 1999;4:23-9.

[24] Rodrigues EMG, Milagres AMF, Pessoa-Júnior A. Xilanase recovery effects of extraction conditions on the AOT-reversed micellar systems using experimental design. Process Biochem 1999;34:121-5. 